\title{
Persistence of shocks in CDS returns on Croatian bonds: Quantile autoregression approach*
}

\author{
Mile Bošnjak ${ }^{1}$ Ivan Novak ${ }^{2}$, Maja Bašic ${ }^{3}$
}

\begin{abstract}
The paper aims to examine persistence of shocks in returns on CDS for $5 Y$ Croatian bonds. Based on sample of daily data from January 6, 2004 up until December 13, 2019 the paper evaluated research hypothesis that assumed persistence of shocks in returns on $5 Y$ Croatian bond. To evaluate the research hypothesis, the paper employed quantile autoregression approach and nonparametric time varying autoregreession approach. The empirical results rejected the research hypothesis assuming persistence of shocks in returns on CDS for $5 Y$ Croatian bonds. Based on the results from this paper, returns on CDS from for $5 Y$ Croatian bonds are in line with efficient market hypothesis for endogenous shocks of small magnitude and at the highest level of endogenous shocks. Furthermore, efficient market hypothesis holds during the calm periods, while during the periods with more dynamics in CDS prices the paper suggests profitable strategy for trader and investors. Eventually, the paper contributes to the ongoing discussion regarding efficient market hypothesis while revealing the case of returns on CDS for $5 Y$ Croatian bonds. Furthermore, the paper suggests trading and investment strategies for investors.
\end{abstract}

Key words: CDS returns, bonds, quantile autoregression, persistence of shocks, efficient market hypothesis

JEL classification: C22, G14, F31, F41

\footnotetext{
* Received: 01-06-2019; accepted: 19-12-2019

1 Assistant Professor, University of Zagreb, Faculty of Economics and Business, JF Kennedy Square 6, 10000 Zagreb, Croatia. Scientific affiliation: international economics, nonlinear econometrics, applied econometrics, neural networks. Phone: +385 12330 374. E-mail: mbosnjak1@net.efzg.hr.Website: https://orcid.org/0000-0002-7663-198X, 56157010000.

2 Assistant Professor, University of Zagreb, Faculty of Economics and Business, JF Kennedy Square 6, 10000 Zagreb, Croatia. Scientific affiliation: international economics, nonlinear econometrics, applied econometrics, neural networks. Phone: +385 1 2330374. E-mail: inovak@efzg.hr.Website: https://orcid.org/0000-0003-1473-7049,56206088900.

3 Postdoctoral Researcher, University of Zagreb, Faculty of Economics and Business, JF Kennedy Square 6, 10000 Zagreb, Croatia. Scientific affiliation: international economics. Phone: +385 12330 374. E-mail: mbasic1@net.efzg.hr.Website: https://orcid.org/0000-0002-1842-7091, 56205616300 .
} 


\section{Introduction}

There is an ongoing debate regarding efficiency of financial markets. Bird et al. (2017) analysed risk premia of Greece, Ireland, Italy, Portugal and Spain on a sample of daily data from October 2009 to November 2015 and pointed out that financial markets often performed in line with efficient market hypothesis. Based on the empirical finding they concluded that efficient market hypothesis approach as well as behavioural approach is need to explain behaviour of financial market. Madhavan and Arrawatia (2016) examined credit default swaps for sovereign bonds of the US, the UK, Japan, Germany, Italy, France and Russia under efficient market hypothesis. Based on their research results CDS on the US bonds were found as the most efficient ones, while CDS on Russian bond are the least efficient. There is a literature gap regarding CDS on bonds of transition countries. Therefore, this paper aims to make a step towards filling this gap with the case of returns on CDS for $5 Y$ Croatian bonds. While examining the case of returns on CDS for $5 Y$ Croatian bonds the goal of the paper is to contribute to the ongoing discussion regarding financial market efficiency and bring practical implication to investors and traders. To achieve this aim and goals working hypothesis tested in this paper assumes persistence of shocks in CDS returns on Croatian bonds. The research hypothesis was tested on a daily data of financial series that is well known to exhibit clustering volatility and non-normality of distributions with fat tails (Bošnjak et al., 2016; Erjavec and Cota, 2007). Therefore, to test the research hypothesis the paper follows quantile autoregression approach and nonparametric time varying autoregression approach, as these two approaches are consistent with empirical properties of financial series.

Reminder of the paper is organised as follows. Literature review section follows the introduction and explains the main theoretical and empirical findings of the efficient market hypothesis. The third section depicts the methodology used in the paper. The fourth section provides descriptive data analysis, the fifth section illustrates the results and the last section concludes the paper.

\section{Literature review}

Efficient market hypothesis states that prices on markets act as signalling mechanism, directing resource allocation (Fama, 1970). Its assumptions include no transaction costs, perfectly and freely available information and perfect competition. As already stated in the Introduction section, empirical literature provides mixed findings regarding validity of efficient market hypothesis (Katusiime et al., 2015) and its ability to predict returns in a time varying manner (Bansal and Yaron, 2004).

In financial markets, the persistence of shocks is based on price volatilities (Zumbach et al., 2000). Shocks result in a reduced predictability of future prices 
(Barro, 1976) and disable the predictability of investors' efficient resource allocation. Moreover, diversification of global investors' portfolio is regime dependant (Consiglio et al., 2018).

Credit derivatives become widely known after the 1997 Asian crisis (Ranciere, 2002). They are used as an instrument of hedging by investors who invest in corporate, municipal and sovereign bonds. Credit default swaps (CDS) are the most commonly used financial derivative, comprising $85 \%$ of all credit derivatives in emerging markets (Ranciere, 2002). CDS allow a buyer of a bond to transfer the risk associated with the bond to the seller, thereby purchasing an insurance against the issuer's inability to meet its obligations usually on 5- or 10-year bonds. Likewise, CDS are a proxy of risk, while the sovereign CDS measure country's health and a probability of default (Ausloos et al., 2016). Furthermore, CDS can predict a country's financial crisis as CDS spreads increase due to a country's inability to repay its debts (Neziri, 2010). The first country that made a CDS payment was Ecuador in 2009, following an inability to repay its interests in 2008 (Noeth and Sengupta, 2014).

Efficient market hypothesis relating to the CDS returns on bonds' dynamics exemplify it as unpredictable and a pure random walk process often examined through GARCH or ARCH processes. CDS of 26 developed and developing countries in the period 2000-2010 shows that global factors are more effective than country fundamentals, especially when default risk as compared to risk premium is taken into account (Longstaff et al., 2011). Conformingly, a study of an August 2011 U.S. sovereign credit rating downgrade on the EU member states' CDS spread pointed to the increase in the CDS spreads and the increase in the probability of the EU member states' default (Blau and Roseman, 2014). Furthermore, the first global CDS regulation introduced in the European Union in 2012 banned the purchase of uncovered sovereign CDS contracts, while the studies showed that CDS spreads increased prior to the regulation, becoming stable after the regulation (Kiesel et al., 2015).

Although Sensoy et al. (2017) confirmed the efficiency of CDS markets of 15 emerging countries, inclusive the time of crisis, Avino and Nneji (2014) doubted the efficiency of the European CDS index market. Namely, after the euroization process neither credit default risk nor risk premiums accurately explain the Eurobond market as global shocks affect the European Union member states differently leading to different asset prices.

Between 1996 and 2017 Republic of Croatia issued 57 bonds on domestic and foreign markets in various currencies: USD, ESP, EUR, JPY and HRK, with the greater amount of bonds of foreign than domestic market and the longest maturity of 15 years (Mihelja Žaja et al., 2018). Using a quarterly data on nominal yields of Croatian government bonds for the periods between Q3 2001 and Q4 2017, Mihelja Žaja et al. (2018) identify structural breaks that occur with economic crisis. In their analysis, before the crisis macroeconomic and fiscal variables influenced 
government bond yields, during the crisis bonds were influenced by financial and political variables, while in the post-crisis period by the macroeconomic variables. Furthermore, in the panel analysis of the Euro area member states and the other EU member states in the period 2007-2016 Kunovac and Pavić (2017) examined the effect of the euro premium on CDS developments. Trifonova et al. (2018) found no statistically significant effects from EONIA to the yield on the Croatian longterm government bonds. In the case of Croatia global influence on the CDS spreads is evident in the effect of the stock market, high yield, volatility premium, bond flows, and regional and global spreads (Longstaff et al., 2011; Kunovac and Pavić, 2017). Moreover, they found that Euro area member states, on average, exhibit lower borrowing costs and higher credit ratings than the other EU member states in the observed period, and that the countries in the Central and Eastern Europe exhibit a higher degree of risk based on the possibility of a government bonds default (Beirne and Fratzscher, 2013, Kunovac and Pavic 2017). Hence, the posttransition countries members of the European Union deserve special attention. While aanalyzing Croatian financial markets on a sample of daily data from the period 2 January 2007 to 31 December 2015 Škrinjarić and Šego (2016) found that regime switching MGARCH outperformed MGARCH specification. Following from papers overviewed in this section, there is no information regarding market efficiency for CDS on Croatian bonds. This paper makes step ahead and fills in the existing gap with case of CDS returns on Croatian bonds.

\section{Methodology}

Securities' equilibrium price corresponds to their expected returns and is a function of risk, which is today higher or equal to tomorrow's price (Fama, 1970, p. 384). Random walk model assumes that the securities' price changes are independent, i.e. identically distributed, and a random walk explains the efficiency of the market hypothesis through its emphasis on expected returns. Hence, by examining the shocks in rate of return on securities we are able to forecast future trends, especially more precisely in the short run (Ang and Bekaert, 2007).

The efficient market hypothesis explains the evolution of investors' tastes through acquisition of new information as in equation (1):

$$
f\left(r_{j, t+1} \mid \Phi_{t}\right)=f\left(r_{j, t+1}\right)
$$

stating that conditional and marginal probability distribution of an independent random variable are identical (Fama, 1970, p. 386).

We firstly examined the property of stationarity using standard standard unit root tests. We employed Augmented Dickey-Fuller (1979) (ADF test), the Generalized 
Least Squares Dickey-Fuller test (DF-GLS) test developed by Elliot et al. (1996) (ERS test) and Phillips-Perron (1988) (PP test) that assume existence of unit root under null hypothesis. Since unit root tests are well known for is low power we additionally employed Kwiatkowski et al. (1992) (KPSS test) that assumes stationary time series under the null hypothesis. In lights of the efficient markets hypothesis we firstly tested persistence of returns on CDS using linear specification of $\mathrm{AR}(1)$ process described in equation (2):

$$
y_{t}=\alpha+\beta \cdot y_{t-1}+\varepsilon_{t}
$$

Where $y_{t}$ presents daily (natural) log returns on CDS, $\beta$ presents dependence on return from previous day that is assumed to be constant, $\alpha$ presents constant term and $\varepsilon_{t}$ presents serially uncorrelated residual term or endogenous shocks. Following Quantile Autoregression (QAR) approach proposed by Koenker and Xiao $(2004,2006), \beta$ coefficient can differ depending on sign and magnitude of endogenous shock. Therefore, to provide deeper insights in dependence structure of autoregression coefficients across different quantiles. AR(1) process at quantile $\tau$ is given in equation (3):

$$
Q_{y_{t}}\left(\tau \mid y_{t-1}\right)=\alpha(\tau) \cdot y_{t-1}+\varepsilon(\tau)
$$

Where: $Q_{y_{t}}\left(\tau \mid y_{t-1}\right)$ denotes the $\tau$-th conditional quantile of the observed series, $\varepsilon(\tau)$ presents $\tau$-th quantile of an endogenous shocks and $\alpha(\tau)$ indicates autoregressive coefficient for each quantile $(\tau)$. Consequently, $\varepsilon(\tau)$ provides information about sign and magnitude of endogenous shock within observed time series while $\alpha(\tau)$ illustrates dependence structure across observed quantiles of endogenous shocks. The standard errors are calculated using the Hall-Sheather bandwidth rule while presuming local (in quantile) linearity of the conditional quantile functions. More details are provided in Koenker and Xiao (2004). Recent papers from Kuck et al. (2015) and Kuck and Maderitsch (2019) employed quantile autoregression approach on exchange rate returns. Conclusively, Quantile autoregression approach reveals dependence structure of returns across different quantiles but we know nothing about time i.e. when certain endogenous shock occurred. To provide information about variation of dependence over the observed period and test robustness of the results we follow nonparametric specification of AR(1) process that is more flexible and robust comparing to parametric one (Robinson,1989). Autoregression model with time-varying parameters was estimated following equation (4):

$$
y_{t}=\alpha_{0}\left(z_{t}\right)+\beta_{1}\left(z_{t}\right) \cdot y_{t-1}+\varepsilon_{t}
$$

Coefficients $\alpha_{0}\left(z_{t}\right)$ and $\beta_{1}\left(z_{t}\right)$ in equation (4) are assumed to be functions of the smoothing variable $\left(z_{t}\right)$ and therefore non-constant. The smoothing variable $\left(z_{t}\right)$ was rescaled with time $z_{t}={ }_{t}^{t} / T$ and therefore $z_{t} \in[0,1]$. 


\section{Empirical data and analysis}

This study analyses daily data on returns on CDS of Croatian bonds (CDS 5Y) for the period 6 January 2004 to 13 December 2019 retrieved from the Bloomberg database. Figure 1 portrays developments of daily CDS price series in (natural) log values and (natural) daily log returns on CDS for the observed period.

Figure 1: Development of price and returns on CDS in (natural) log values
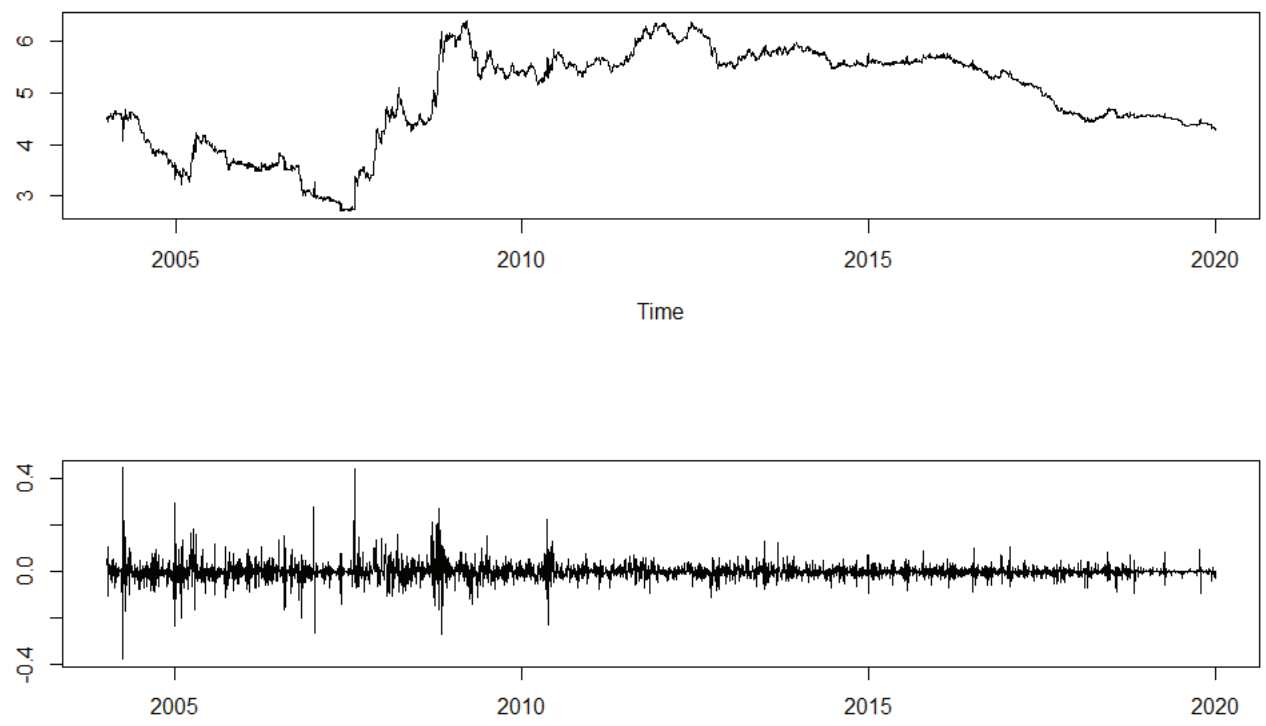

Source: Bloomberg. Authors' calculations

Figure 1 illustrates more dynamics in returns on CDS during the first half of the sample period. Before the financial and economic crises that started in 2007/2008 the price of CDS on Croatian bond was decreasing and there was sharp increase in price the CDS during the crises. Afterwards, there was no such sharp changes in CDS price. Following empirical procedure described in section entitled Methodology, Table 1 summarizes unit root test results.

Table 1: Unit root tests (including intercept and trend)

\begin{tabular}{|c|c|c|c|c|}
\hline Variable & ADF test & PP test & KPSS test & ERS test \\
\hline $\log \left(C D S_{t}\right)$ & -0.897783 & -0.946206 & 1.438712 & -1.077388 \\
\hline$r_{t}$ & -64.34824 & -64.36639 & 0.123334 & -3.458854 \\
\hline
\end{tabular}

Source: Authors' calculations 
The results in Table 1 unambiguously pointed out existence of unit root in CDS prices series while CDS returns series are found stationary. Based on the results from unit root test, the rests of the analysis examine the returns on CDS. Descriptive statistic for returns on CDS $5 Y$ for Croatian bonds were presented in Table 2.

Table 2: Descriptive statistic of the observed series

\begin{tabular}{|l|c|}
\hline & $r_{t}$ \\
\hline Mean & $-5.53 \mathrm{E}-05$ \\
Median & 0.000000 \\
Maximum & 0.447978 \\
Minimum & -0.377343 \\
Std. Dev. & 0.034926 \\
Skewness & 1.141656 \\
Kurtosis & 28.94116 \\
\hline ARCH LM-test & 367.85 \\
\hline Probability & $<2.2 \mathrm{e}-16$ \\
\hline Jarque-Bera & 117490.8 \\
Probability & 0.000000 \\
\hline Observations & 4158 \\
\hline
\end{tabular}

Source: Authors' calculations

Descriptive statistics in Table 2 reveal empirical properties of (natural) log returns on CDS for Croatian bond. Firstly, mean return is close to zero and median returns amounts zero. Therefore, holding CDS on Croatian bonds for the whole observation period makes almost no earnings. Furthermore, Jarque-Bera test statistics rejects the null hypothesis that assumes normal distribution of returns and ARCH LMtest indicate existence of ARCH effects as it is usually the case in financial series. Non-normality of distribution and ARCH effect violate the desired properties of OLS (Ordinary Least Squares) as an estimator while Quantile autoregression approach and nonparametric approach are consistent with empirical properties of the observed series. However, as a starting point and just for the comparison Table 3 summarizes the estimates from linear autoregressive process of order one - AR(1) process.

Table 3: Linear OLS estimates of AR(1) process for returns on CDS for Croatian bonds

\begin{tabular}{|l|c|c|c|c|}
\hline \multicolumn{1}{|c|}{ Variable } & Coefficient & Std. Error & t-Statistic & Probability \\
\hline $\mathrm{C}$ & $-6.83 \mathrm{E}-05$ & 0.000542 & -0.126033 & 0.8997 \\
\hline $\mathrm{AR}(1)$ & 0.001951 & 0.015511 & 0.125795 & 0.8999 \\
\hline
\end{tabular}

Source: Authors' calculations 
Table 3 illustrate estimates for AR(1) process of returns on CDS for Croatian bonds. The results support efficient market hypothesis since AR(1) coefficient was not statistically distinguishable from zero. However, bearing in mind empirical properties of distribution of returns on CDS for Croatian bonds we further analyzed the returns on CDS using the more convenient methods as described in the Methodology section.

Following equation (3) in Methodology section quantile autoregression model was estimated and results are summarized in Table 4.

Table 4: Quantile dependent estimates of returns on CDS of Croatian bond

\begin{tabular}{|c|c|c|c|c|c|c|}
\hline \multirow[b]{2}{*}{ Quantile } & \multicolumn{3}{|c|}{$\varepsilon(\tau)$} & \multicolumn{3}{|c|}{$\alpha(\tau)$} \\
\hline & $\begin{array}{c}\text { Estimates } \\
\text { (standard errors) }\end{array}$ & t-statistic & p-value & $\begin{array}{c}\text { Estimates } \\
\text { (standard errors) }\end{array}$ & t-statistic & p-value \\
\hline 0.05 & $\begin{array}{l}-0.04652 \\
(0.00204)\end{array}$ & -22.82806 & 0.00000 & $\begin{array}{l}-0.09409 \\
(0.01962)\end{array}$ & -4.79444 & 0.00000 \\
\hline 0.10 & $\begin{array}{l}-0.03031 \\
(0.00099)\end{array}$ & -30.56259 & 0.00000 & $\begin{array}{l}-0.09511 \\
(0.02765)\end{array}$ & -3.44002 & 0.00059 \\
\hline 0.15 & $\begin{array}{l}-0.02190 \\
(0.00073) \\
\end{array}$ & -29.86719 & 0.00000 & $\begin{array}{l}-0.06449 \\
(0.01795) \\
\end{array}$ & -3.59352 & 0.00033 \\
\hline 0.20 & $\begin{array}{l}-0.01641 \\
(0.00061)\end{array}$ & -26.85616 & 0.00000 & $\begin{array}{l}-0.05485 \\
(0.01704)\end{array}$ & -3.21842 & 0.00130 \\
\hline 0.25 & $\begin{array}{l}-0.01213 \\
(0.00055)\end{array}$ & -22.17291 & 0.00000 & $\begin{array}{l}-0.04112 \\
(0.01376)\end{array}$ & -2.98794 & 0.00283 \\
\hline 0.30 & $\begin{array}{l}-0.00855 \\
(0.00049) \\
\end{array}$ & -17.55360 & 0.00000 & $\begin{array}{l}-0.02953 \\
(0.00813) \\
\end{array}$ & -3.63261 & 0.00028 \\
\hline 0.35 & $\begin{array}{l}-0.00536 \\
(0.00043)\end{array}$ & -12.50105 & 0.00000 & $\begin{array}{l}-0.00617 \\
(0.01152)\end{array}$ & -0.53524 & 0.59251 \\
\hline 0.40 & $\begin{array}{l}-0.00272 \\
(0.00038)\end{array}$ & - 7.22775 & 0.00000 & $\begin{array}{l}-0.00347 \\
(0.01038)\end{array}$ & -0.33396 & 0.73843 \\
\hline 0.45 & $\begin{array}{l}-0.00017 \\
(0.00022)\end{array}$ & -0.78453 & 0.43278 & $\begin{array}{l}-0.00062 \\
(0.00624)\end{array}$ & -0.09867 & 0.92141 \\
\hline 0.50 & $\begin{array}{r}0 \mathrm{e}+00 \\
(4 \mathrm{e}-05)\end{array}$ & 0.00000 & 1.00000 & $\begin{array}{r}0 \mathrm{e}+00 \\
(1 \mathrm{e}-03)\end{array}$ & 0 & 1.00000 \\
\hline 0.55 & $\begin{array}{r}0.00000 \\
(0.00008)\end{array}$ & 0.00000 & 1.00000 & $\begin{array}{l}0.00000 \\
(0.0021)\end{array}$ & 0.00000 & 1.00000 \\
\hline 0.60 & $\begin{array}{r}0.00065 \\
(0.00026)\end{array}$ & 2.50562 & 0.01226 & $\begin{array}{r}0.00834 \\
(0.00692)\end{array}$ & 1.20571 & 0.22800 \\
\hline 0.65 & $\begin{array}{r}0.00346 \\
(0.00041)\end{array}$ & 8.34004 & 0.00000 & $\begin{array}{r}0.01291 \\
(0.01032)\end{array}$ & 1.25137 & 0.21087 \\
\hline 0.70 & $\begin{array}{r}0.00636 \\
(0.00046)\end{array}$ & 13.83243 & 0.00000 & $\begin{array}{r}0.02649 \\
(0.01041)\end{array}$ & 2.54492 & 0.01097 \\
\hline 0.75 & $\begin{array}{r}0.00999 \\
(0.00056) \\
\end{array}$ & 17.75494 & 0.00000 & $\begin{array}{r}0.02691 \\
(0.01508) \\
\end{array}$ & 1.78396 & 0.07450 \\
\hline 0.80 & $\begin{array}{r}0.01430 \\
(0.00063) \\
\end{array}$ & 22.70674 & 0.00000 & $\begin{array}{r}0.03748 \\
(0.01741) \\
\end{array}$ & 2.15286 & 0.03139 \\
\hline 0.85 & $\begin{array}{r}0.02018 \\
(0.00079)\end{array}$ & 25.55517 & 0.00000 & $\begin{array}{r}0.06213 \\
(0.01998)\end{array}$ & 3.10956 & 0.00189 \\
\hline
\end{tabular}


Mile Bošnjak, Ivan Novak, Maja Bašić • Persistence of shocks in CDS returns...

\begin{tabular}{|c|r|c|c|r|r|r|}
\hline \multirow{2}{*}{ Quantile } & \multicolumn{3}{|c|}{$\varepsilon(\tau)$} & \multicolumn{3}{|c|}{$\alpha(\tau)$} \\
\cline { 2 - 7 } & $\begin{array}{r}\text { Estimates } \\
\text { (standard errors) }\end{array}$ & t-statistic & p-value & $\begin{array}{r}\text { Estimates } \\
\text { (standard errors) }\end{array}$ & t-statistic & p-value \\
\hline 0.90 & $\begin{array}{r}0.02952 \\
(0.00122)\end{array}$ & 24.21924 & 0.00000 & $\begin{array}{r}0.06925 \\
(0.02880)\end{array}$ & 2.40410 & 0.01626 \\
\hline 0.95 & $\begin{array}{r}0.04879 \\
(0.00211)\end{array}$ & 23.16707 & 0.00000 & $\begin{array}{r}0.06328 \\
(0.05306)\end{array}$ & 1.19258 & 0.23310 \\
\hline
\end{tabular}

Source: Authors' calculations

The results in Table 4 illustrate autoregression coefficients across different quantile of endogenous shocks. For the negative endogenous shocks of the highest magnitude, the autoregression coefficient is negative and statistically significant. Therefore, negative shocks of the highest magnitude were followed by positive returns in a next day pointing out opportunity for investors and rejecting the efficient market hypothesis. The same situation holds until quantile 0.35 where statistical significance of autoregression coefficient diminishes and supports efficient market hypothesis. Following estimates in Table 4, autoregression coefficient was not significant and efficient market hypothesis was hold up to quantile 0.70. At the quantile 0.70 autoregression coefficient obtain its statistical significance again while rejecting efficient market hypothesis. Furthermore, autoregression coefficients turned to be positive. Therefore, positive endogenous shocks were followed by positive next day returns indicating opportunity for investors and suggesting buy and hold strategy when price of CDS goes up. There was the same situation up until the highest magnitude of endogenous shock where autoregression coefficient lost its statistical significance pointing out validity of efficient market hypothesis at the highest positive endogenous socks. The results from Table 4 were illustrated in Figure 2. 
Figure 2: Endogenous shocks (intercept) and autoregression coefficient
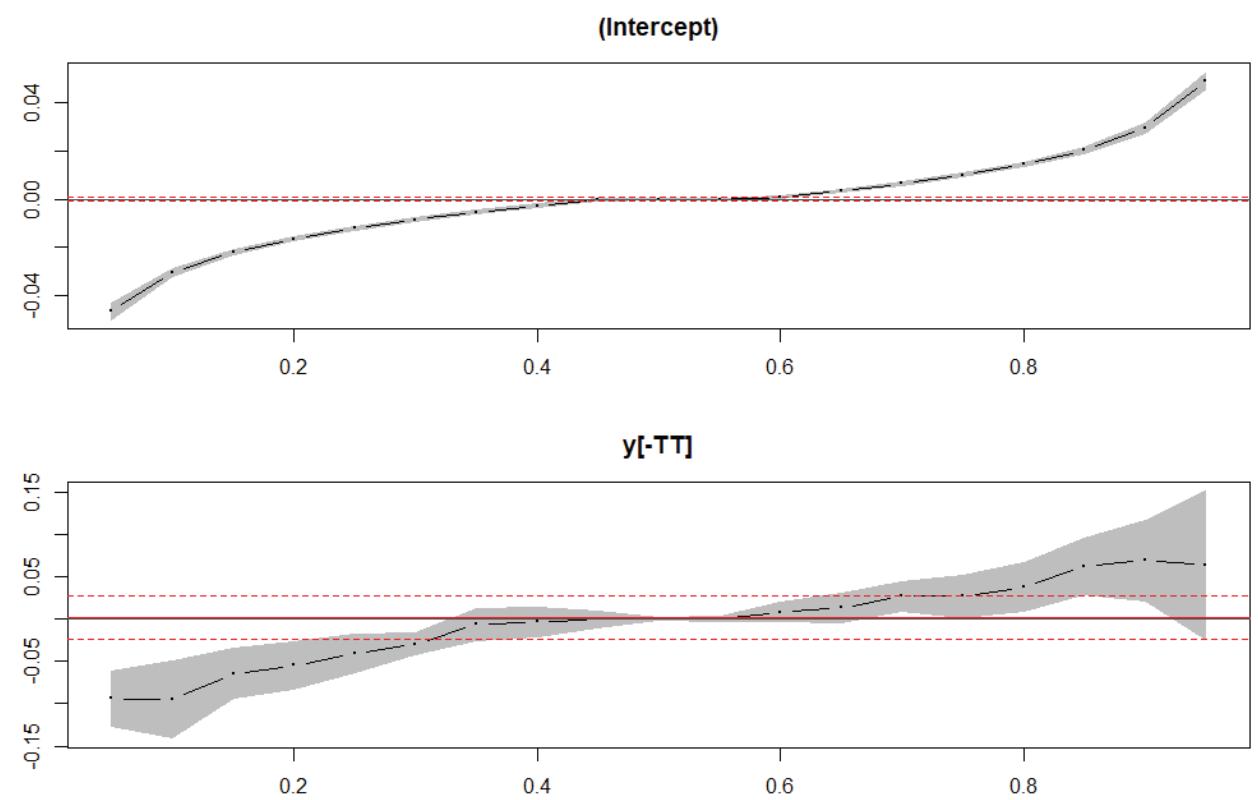

Source: Authors' calculations

Conclusively and following the results presented in Figure 2, estimates from the quantile autoregression point to no persistence and asymmetries in returns on CDS for Croatian bonds and support efficient market hypothesis around the median and at the highest level of positive endogenous shocks. Nonetheless, as previously stated in the Methodology section, quantile autoregression reveals dependence structure across different quantile of endogenous shocks, but we know nothing about when certain endogenous shocks occurred. To reveal time dependence of autoregression coefficient we further estimated nonparametric time varying autoregression model. While suppressing constant term $\left(\alpha_{0}\left(z_{t}\right)\right)$ in equation (4) we estimated the model specification comparable with quantile autoregression specification. The results are summarized in Table 5. 
Table 5: Summary of time-varying estimated coefficients

\begin{tabular}{|l|c|c|c|}
\hline \multicolumn{3}{|c|}{ AR(1) } & \multicolumn{2}{c|}{$95 \%$ CI } \\
\hline Min. & -0.307464 & -0.56402 & -0.081777 \\
\hline 1st Qu. & -0.137863 & -0.26413 & -0.002881 \\
\hline Median & -0.027697 & -0.16814 & 0.109376 \\
\hline Mean & -0.003129 & -0.14438 & 0.138123 \\
\hline 3rd Qu. & 0.179095 & 0.04088 & 0.314625 \\
\hline Max. & 0.283734 & 0.11972 & 0.448145 \\
\hline \multicolumn{2}{|c|}{ Pseudo R-squared: 0.0394} \\
\hline
\end{tabular}

Source: Authors' calculations

Table 5 shows the estimates of autoregression coefficient and bootstrap confidence intervals. The results in Table 5 illustrate somewhat higher autoregression coefficient but still no persistence. Furthermore, we illustrated the estimates of autoregression coefficients and residuals (endogenous shocks) in Figure 3.

Figure 3: Residuals and estimates of time varying autoregression coefficient

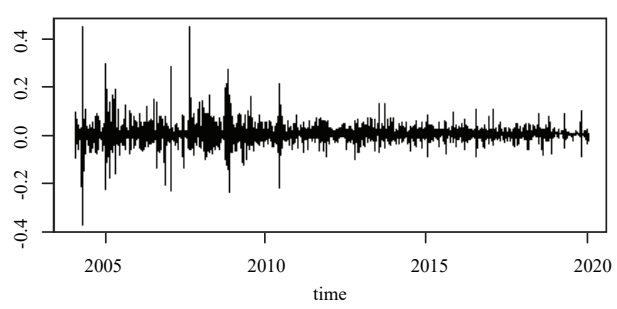

Source: Authors' calculations



On the left-hand side of Figure 3, one can see the residuals from nonparametric time varying autoregression model and its development over the observed period. The right-hand side of Figure 3 illustrates the time development of autoregression coefficient and corresponding confidence intervals. It is useful to compare these results with those illustrated in Figure 1. The periods with more dynamics in Figure 1 corresponds to the endogenous shocks of higher magnitude (either positive or negative) in Figure 3. The autoregression coefficient increased during the crises as illustrated in Figure 3. Therefore, efficient market hypothesis might be rejected at periods of crises and high dynamics on CDS market while calm periods were in line with efficient market hypothesis. These results are consistent with estimates from quantile autoregression specification where efficient market hypothesis was supported around the median of endogenous shocks. 


\section{Results and discussion}

Research results from this paper in line with finding from previous recent studies (Bird et al., 2017; Madhavan and Arrawatia, 2016) supported efficient market hypothesis and behavioral approach as well. Depending on sign and magnitude of endogenous shocks in CDS returns on Croatian bonds, efficient market hypothesis holds around median and at the highest quantile of endogenous shocks. Therefore, endogenous shocks of small magnitude in its absolute value as well as the largest positive endogenous shocks behave as predicted by efficient market hypothesis. However, research results from this paper suggest some profitable trading and investment strategies that can be considered as practicable implications from this paper. The traders with CDS on Croatian bonds might benefit when price of CDS on Croatian bonds decline by sizable amount and the traders buy the CDS at declined price. In a following day, the CDS price is expected to increase and traders should sell the CDS at increased price. Therefore, active trading strategy is suggested as profitable when price of the CDS decrease by sizable amounts. However, active trading strategy includes more transaction costs and traders need to buy larger number of CDS to make a profit. When the price of the CDS increases by its larger amount but not the largest, buy and hold strategy is suggested since the increase in price is followed by next day increase in price. Therefore, in this case investors are suggested to take long position in the CDS. Eventually, previous studies considered difference in behavior of financial markets during the crisis (see for example Mihelja Žaja et al., 2018). Research results from this paper suggest that efficient market hypothesis holds during the calm periods on financial market when no big changes in the CDS price occurs. While in periods of crisis characterized with big and unexpected changes in prices of the CDS behavioral approach is more convenient to explain dynamics of CDS price. Findings from this paper suggest that times of crisis are provide an opportunity for traders and investors to make a profit. Evidently, the CDS prices exhibits nonlinearity and quantile autoregrssion approach from Koenker and Xiao $(2004,2006)$ employed in this paper is found well-suited specification to capture nonlinearities and empirical properties of distribution of the CDS prices. Nonparametric time varying parameters approach from Robinson (1989) contributes to make a picture complete since it provides insights in development of the process over the time that cannot be seen from quantile autoregression estimates.

\section{Conclusions}

This paper analyzed the persistence of endogenous shocks in returns on CDS of Croatian bonds. Empirical results from this paper reject hypothesized persistence of shocks in returns on CDS for Croatian bonds. It portrays the financial system's intertemporal ability to accommodate financial shocks in a self-corrective manner thereby showing the effect of a financial contagion into a real economy. Reviewed 
literature suggested that Croatia CDS explicate the country risk in which the global transmission mechanism is not dominant. The analysis has pointed towards the asymmetric persistence of endogenous shocks in returns on CDS of Croatian bonds depending on a sign and magnitude of endogenous shocks. The quantile autoregression approach has shown that at the lowest as well as at the higher quantiles of endogenous shocks the efficient market hypothesis was rejected, while the efficient market hypothesis holds around the median and at highest quantile of endogenous shocks. The results indicated asymmetries in returns and suggest profitable strategies for investors depending on direction and magnitude of change in CDS prices. The results illustrated estimates from nonparametric time varying autoregression model specification while comparing the results with estimates from quantile autoregression specification and development of the observed series. The comparison indicated that endogenous shocks of higher magnitudes appeared before and during the crises from 2007/2008 and it is likely that the efficient market hypothesis holds during the times with more dynamics on CDS market. Following the results from this paper, the efficient market hypothesis is expected to hold during calm periods on CDS market. The novelty of the paper and its scientific contribution stem from the obtained asymmetries in persistence of endogenous shocks in returns on CDS of Croatian bonds depending on the magnitude of the shock. Namely, as the contemporary empirical literature still did not arrive to an unambiguous relationship between the efficient market hypothesis and returns on CDS of bonds dynamics, especially from the perspective of the transition country's economy. Hereby, the magnitude of endogenous shock could result in differing responses of policy-makers. The limitation of this research is data availability and further research should be directed towards research sample expanded with inclusion other transition countries that would enable identification common and country specific drivers of shocks.

\section{References}

Ang, A., Bekaert, G. (2007) "Stock return predictibility: Is it there?" Review of Financial Studies, Vol. 20, No. 3, pp. 651-707, http://doi.org/10.1093/rfs/hhl021.

Ausloos, M., Castellano, R., Cerqueti, R. (2016) "Regularities and Discrepancies of Credit Default Swaps: a Data Science approach through Benford's Law", available online at: https://arxiv.org/pdf/1603.01103.pdf (1 April 2019).

Avino, D., Nneji, O. (2014) "Are CDS spreads predictable? An analysis of linear and non-linear forecasting models" International Review of Financial Analysis, Vol. 34, pp. 262-274, http://doi.org/10.1016/j.irfa.2014.04.001.

Bansal, R., Yaron, A. (2004) "Risks for the long run: A potential resolution of asset pricing puzzles" Journal of Finance, Vol. 59, No. 4, pp. 1481-1509, http://doi. $\operatorname{org} / 10.1111 / \mathrm{j} .1540-6261.2004 .00670 . x$. 
Barro, R.J. (1976) "Rational expectations and role of monetary policy" Journal of Monetary Economics, Vol. 2, No. 1, pp. 1-32. Available at: http://www. sciencedirect.com/science/article/pii/0304-3932(76)90002-7.

Beirne, J., Fratzscher, M. (2013) "The pricing of sovereign risk and contagion during the European sovereign debt crisis" Journal of International Money and Finance, Vol. 34, pp. 60-82, http://doi.org/10.1016/j.jimonfin.2012.11.004.

Bird, G., Du, W., Willett, T. (2017) "Behavioral finance and efficient markets: What does the euro crisis tell us?" Open Economies Review, Vol. 28, No. 2, pp. $273-$ 295, https://doi.org/10.1007/s11079-017-9436-1.

Blau, B., Roseman, B.S. (2014) "The reaction of European credit default swap spreads to the U.S. credit rating downgrade", International Review of Economics and Finance, Vol. 34, pp. 131-141, http://doi.org/10.1016/j.iref.2014.07.009.

Bošnjak, M., Bilas, V., Novak, I. (2016) "Modeling exchange rate volatilities in Croatia" Ekonomski vjesnik/Econviews-Review of Contemporary Business, Entrepreneurship and Economic Issues, Vol. 29, No. 1, pp. 81-94. Available at: https:/hrcak.srce.hr/ojs/index.php/ekonomski-vjesnik/article/view/3951/2448.

Consiglio, A., Lotfi, S., Zenios, S.A. (2018) "Portfolio diversification in the sovereign credit swap markets", Annals of Operation Research, Vol. 266, No. 1-2, pp. 5-33, http://doi.org/10.1007/s10479-017-2565-5.

Dickey, D. A., Fuller, W. A. (1979) "Distribution of the estimators for autoregressive time series with a unit root", Journal of the American statistical association, 74 (366a), pp. 427-431, http://doi.org/10.1080/01621459.1979.10482531.

Elliott, G. Rothenberg, T. J., Stock, J. H. (1996) "Efficient Tests for an Autoregressive Unit Root", Econometrica, 64(4), pp. 813-836, http://doi.org/ $10.3386 / \mathrm{t} 0130$.

Erjavec, N., Cota, B. (2007) "Modeling stock market volatility in Croatia" Economic research-Ekonomska istraživanja, Vol. 20, No. 1, pp. 1-7. Available at: https:// hrcak.srce.hr/index.php?show=clanak\&id_clanak_jezik=33786.

Fama, E.F. (1970) "Efficient Capital Markets: A Review of Theory and Empirical Work", The Journal of Finance, Vol. 25, No. 2, Papers and Proceedings of the Twenty-Eighth Annual Meeting of the American Finance Association New York, N.Y. December, 28-30, 1969, pp. 383-417, http://doi.org/10.2307/ 2325486, https://www.jstor.org/stable/2325486.

Katusiime, L., Shamsuddin, A., Agbola, F. W. (2015) "Foreign exchange market efficiency and profitability of trading rules: Evidence from a developing country" International Review of Economics \& Finance, Vol. 35, pp. 315-332, http://doi.org/10.1016/j.iref.2014.10.003.

Kiesel, F., Lücke, F., Schiereck, D. (2015) "Regulation of uncovered sovereign credit default swaps - evidence from the European Union", The Journal of Risk Finance, Vol. 16, No. 4, pp. 425-443, http://doi.org/10.1108/JRF-02-20150025 . 
Koenker, R., Xiao, Z. (2004) "Unit root quantile autoregression inference”, Journal of the American Statistical Association, 99 (467), pp. 775-787, http://doi.org/ $10.1198 / 016214504000001114$.

Koenker, R., Xiao, Z. (2006) "Quantile autoregression", Journal of the American Statistical Association, 101 (475), pp. 980-990, http://doi.org/10.1198/ 016214506000000672.

Kuck, K., Maderitsch, R. (2019) "Intra-day dynamics of exchange rates: New evidence from quantile regression", The Quarterly Review of Economics and Finance, Vol. 71, pp. 247-257, http://doi.org/10.1016/j.qref.2018.09.001.

Kuck, K., Maderitsch, R., Schweikert, K. (2015) "Asymmetric over-and undershooting of major exchange rates: evidence from quantile regressions", Economics Letters, Vol. 126, pp. 114-118, http://doi.org/10.1016/j.econlet.2014.11.028.

Kunovac, D., Pavić, N. (2017) "Can the Adoption of the Euro in Croatia Reduce the Cost of Borrowing?" Croatian National Bank, Survey $S$ - 28, Available online at: https://www.hnb.hr/documents/20182/2070711/s-028.pdf/e94561ba-762a443e-8061-1dfa641fca4e (1 April 2019).

Kwiatkowski, D., Phillips, P., Schmidt, P., Shin, Y. (1992) "Testing the Null Hypothesis of Stationarity Against the Alternatives of a Unit Root: How Sure Are We That Economic Time Series Have a Unit Root?", Journal of Econometrics, Vol. 54, pp. 159-178, http://doi.org/10.1016/0304-4076(92)90104-Y.

Longstaff, F. A., Pan, J., Pedersen, L.H., Singleton, K.J. (2011) "How Sovereign Is Sovereign Credit Risk?" American Economic Journal: Macroeconomics, Vol. 3, No. 2, pp. 75-103, http://doi.org/10.1257/mac.3.2.75.

Madhavan, V., Arrawatia, R. (2016) "Relative efficiency of G8 Sovereign credit default swaps and bond scrips: an adaptive market hypothesis perspective" Studies in Microeconomics, Vol. 4, No. 2, pp. 127-150, http://doi.org/10.1177\% 2F2321022216649479.

Mihelja Žaja, M., Jakovčević, D., Višić, L. (2018) “Determinants of the government bond yield: Evidence from a highly euroised small open economy" International Journal of Economic Sciences, Vol. 7, No. 2, pp. 87-106, http://doi.org/ 10.20472/ES.2018.7.2.005.

Neziri, H. (2010) "Can Credit Default Swaps Predict Financial Crises? Empirical Study on Emerging Markets", Carroll Round Proceedings, Vol. 5, pp. 3-28. Available online at: https://repository.library.georgetown.edu/bitstream/ handle/10822/707337/CRP-V.pdf (1 April 2019).

Noeth, B., Sengupta, R. (2014) "A Look at Credit Default Swaps and Their Impact on the European Debt Crisis", The Regional Economist, available online at: https://www5.cob.ilstu.edu/jwtrefz/files/2014/12/360ReadingTopic14StLCDS. pdf (1 April 2019).

Phillips, P.C.B., Perron P. (1988) "Testing for a unit root in time series regression", Biometrika, Vol. 75, pp. 335-346, http://doi.org/10.1093/biomet/75.2.335. 
Ranciere, R.G. (2002) "Credit Derivatives in Emerging Markets". International Monetary Fund Policy Discussion Paper, available online at: https://repositori. upf.edu/bitstream/handle/10230/1080/856.pdf?sequence=1 (1 April 2019).

Robinson, P. M. (1989) "Nonparametric estimation of time-varying parameters. In Statistical Analysis and Forecasting of Economic Structural Change", pp. 253264, Springer, Berlin, Heidelberg, http://doi.org/10.1007/978-3-662-02571$0 \_15$.

Sensoy, A., Fabozzi, F.J., Eraslan, V. (2017) "Predactibility dynamics of emerging sovereign CDS markets" Economic Letters, Vol. 161, pp. 5-9.

Škrinjarić, T., Šego, B. (2016) "Asset allocation and regime switching on Croatian financial market", Croatian Operational Research Review, Vol. 7, No. 2, pp. 201-2015, http://doi.org/10.17535/crorr.2016.0014.

Trifonova, S., Atanasov, A., Kolev, S. (2018) "The Effects of the ECB's Unconventional Monetary Policy on the Non-Euro Area EU Member States" 7th International Scientific Symposium on Economy of Eastern Croatia - Vision And Growth Location: Osijek, Croatia, May 24-26, 2018. Book Series: Međunarodni Znanstveni Simpozij Gospodarstvo Istocne Hrvatske-Jucer Danas Sutra, pp. 1131-1144.

Zumbach, G.I., Dacorogna, M.M., Olsen, J.L., Olsen, R.B. (2000) "Measuring shock in financial markets" International Journal of Theoretical and Applied Finance, Vol. 3, No. 3, pp. 347-355. 


\title{
Postojanost endogenih šokova u prinosima na CDS za obveznice Republike Hrvatske: Pristup kvantilne regresije
}

\author{
Mile Bošnjak ${ }^{1}$, Ivan Novak ${ }^{2}$, Maja Bašićc
}

\begin{abstract}
Sažetak
Cilj rada je ispitati postojanost endogenih šokova u prinosima na CDS koji se temelje na petogodišnjim obveznicama Republike Hrvatske. Na temelju uzorka dnevnih podataka od 6. siječnja 2004. do 13. prosinca 2019. godine u radu se provjerava hipoteza istraživanja koja pretpostavlja postojanost šokova u prinosu na CDS-ove, a koji se temelje na petogodišnjim obveznicama Republike Hrvatske. Kako bi se provjerila hipoteza istraživanja, rad primjenjuje pristup kvantilne autoregresije $i$ pristup neparametrijske, vremenski promjenjive autoregresije. Empirijski rezultati odbacili su hipotezu istraživanja koja je pretpostavljala postojanost šokova u prinosima na CDS koji se temelje na petogodišnjim obveznicama Republike Hrvatske. Na temelju rezultata ovog rada, prinosi na CDS bazirani na petogodišnjim obveznicama Republike Hrvatske su u skladu s hipotezom o efikasnim tržištima za endogene šokove male magnitude i onima na najvišem kvantilu endogenih šokova. Nadalje, hipoteza o efikasnosti tržišta vrijedi tijekom mirnih razdoblja u kretanju cijena CDS- $a$, dok tijekom dinamičnih razdoblja ovaj rad sugerira profitabilnu strategiju za trgovca i investitore. $\mathrm{Na}$ kraju, rad doprinosi neprestanoj raspravi o hipotezi učinkovitog tržišta, otkrivajući slučaj povrata na CDS koji se temelji na petogodišnjim obveznicama Republike Hrvatske. Nadalje, u radu se predlažu strategije trgovanja $i$ ulaganja za investiture.
\end{abstract}

Ključne riječi: prinosi na CDS, obveznice, kvantilna autoregresija, postojanost šokova, hipoteza o efikasnim tržištima

JEL klasifikacija: C22, G14, F31, F41

${ }^{1}$ Docent, Sveučilište u Zagrebu, Ekonomski fakultet, Trg J. F. Kennedyja 6, 10000 Zagreb, Hrvatska. Znanstveni interes: međunarodna ekonomija, nelinearna ekonometrija, primijenjena ekonometrija, neuronske mreže, Tel.: +38512330 374.E-mail: mbosnjak1@net.efzg.hr.Web stranica: https://orcid.org/0000-0002-7663-198X. 56157010000.

2 Docent, Sveučilište u Zagrebu, Ekonomski fakultet, Trg J. F. Kennedyja 6, 10000 Zagreb, Hrvatska. Znanstveni interes: međunarodna ekonomija, nelinearna ekonometrija, primijenjena ekonometrija, neuronske mreže.Tel.: +38512330374.E-mail: inovak@efzg.hr. Web stranica: https://orcid.org/0000-0003-1473-7049, 56206088900.

${ }^{3}$ Poslijedoktorand, Sveučilište u Zagrebu, Ekonomski fakultet, Trg J. F. Kennedyja 6, 10000 Zagreb, Hrvatska. Znanstveni interes: međunarodna ekonomija. Tel.: +385 12330 374. E-mail: mbasic1@net.efzg.hr.Web stranica: https://orcid.org/0000-0002-1842-7091, 56205616300. 